\title{
衝動型・熟慮型認知スタイルの走査方略に関する分析的研究
}

一一走查方略と項目位置および項目内の位置関倸について——

山崎晃*

\section{AN ANALYTICAL STUDY OF VISUAL SCANNING STRATEGIES OF A REFLECTION-IMPULSIVITY}

\section{Akira YAMAZAKI}

\begin{abstract}
Failure was hypothesized as an antecedent of a reflective style of responding and a quick response as an antecedent of an impulsive style. Failure was manipulated with an instruction to respond correctly (conditioned instruction), and effects and scanning strategies on the MFFT were assessed. The impulsives showed much higher rate in the standard-figure fixation than the reflectives on the MFFT and this result made previous studies acceptable. Scanning strategy patterns were returns 1,2 and 3 , runs 1,2 and 3 . The reflectives showed higher rate than the impulsives in each of these patterns in the normal instruction condition of the first three items (1-3). But, these differences were not found in the last three items (10-12) in the conditioned instruction. Subsequently several implications of these results for the scanning strategy patterns of cognitive style were discussed.
\end{abstract}

Key words : cognitive style, scanning strategy, instruction, antecedent variable

これまで認知スタイルと呼ばれてきたものにはいくつ かの種類があるが，その中で衝動型・熟慮型次元の認知 スタイルは個人差を示す指標としての市民権を次第に獲 得してきている(臼井, 1975)。衝動型・熟慮型の生じる 背景については「失敗すること」や「反応の遅いこと」 にかかわる不安 (Kagan \& Kogan, 1970)，自尊心の高低 (Brockner, 1979 ; 田中, 1984) などの要因があげられる。こ のような規定要因についての研究と関連して，これらの 要因が課題解決の方略にどのように影響するかを研究す る必要がある。衝動型・熟慮型の認知スタイルが認知過 程における個人差ないしは情報処理様式をあらわすもの (日井，1975）であれば, Matching Familiar Figures Test (MFFT) 課題を解決する際の両認知スタイルの方略 の違いについて検討することは，認知スタイルの規定要 因あるいは先行変数について検討することに関連するで あろう。すなわち, 衝動型・熟慮型が反応潜時の長短,

* 滋賀大学教育学部 (Department of Child Psychology, Fuculty of Education, Shiga University.)
誤反応数の多少，ある特定の走查方略のパターンの出現 回数の多少のように単なる量的な違いをもつだけのもの であるかあるいはもっと本質的な違いがあるかを祫討し， さらに教示によるそのパターンの変容のしかたについて 検討することは衝動型・熟慮型の認知スタイルの生じる 背景について明らかにすることになる。

走査方略に関する研究の知見は必ずしも一致していな い。第 1 に衝動型と熟慮型間の標準刺激注視率について, 衝動型児童の標準刺激注視率が高い(Siegelman, 1969 ; 白 井，1975），熟慮型皃童の方が高い傾向にある(Drake， 1970), 両認知スタイル間には差がない (Zelniker et al., 1972 ；佐藤，1976）とする研究などがある。

第 2 に走査方略について, 熟慮型は選択刺激間の特徵 に注目して標準刺激のそれと比較することによって正答 を求めるが，衝動型は特定の少数の刺激の比較だけで正 答と思われるものを選択しやすいとする研究 (Siegelman, 1969 ; Drake, 1970) がある。また, Drake (1970) は熟虑 型が除去法を用いやすいと述べている。一方，Zelniker 
et al. (1972) や Ault et al. (1972) は, 反応潜時の長短 にかかわる標準刺激と比較刺激間あるいは比較刺激間の 同一部分比較であるリターンの全注視数に占める割合に ついては衝動型と熟虑型間に差がみられたが，本質的に は両認知スタイルに特有な走查方略はないと言う。また， 熟虑型は刺激間を比較していく際に「同一部分比較」 「連続比較」などの組織的な比較パターンを用いること が必ずしも多いとはいえず，両認知スタイル間には走査 方略パターンには本質的な違いはみられないとする研究 （佐藤，1976）もある。

本研究では両認知スタイルに特有な走查方略があるの か。それとも単に課題の特性に依存する差異であるのか。 すなわち, MFFT 課題が単に視覚的な情報処理の面を 検討したものであり，その結果は情報を求めれば求める ほど誤りの可能性を減らすような課題による(佐藤, 1976) ものであり，そのために両認知スタイル間の差異は単な る量的な多少を示したものにすぎないものであるかにつ いて検討する。

ところで, 従来のほとんどの研究では MFFT 12項目 全体がまとめて分析されてきた。しかし, Reali \& Hall （1970）によれば, 誤反応の直後には成功への期待が低下 しより慎重な反応が行われやすく, 正反応の後では成功 への期待が上昇するがそれは反応潜時にはほとんど関係 がないと言う。このような期待や慎重な態度は走查方略 などにも影響を与えると考えられ，最初の 1 項目から最 終の12項目までの間に走査方略パターンは変化する可能 性がある。さらに, 失敗経験後には慎重な反応が行われ やすくなり熟虑的な反応傾向が強められると考えられ る。

また，熟慮型が除去法の方略を用いるならば 1 項目内 での注視パターンは後半になるにつれて次第に限定され たもの（たとえば，特定の刺激間の比較）に変化していくと 考えられる。そこで本実験ではそのような点に配虑し， 12項目を前半・中盤・後半に分け, 前半と後半の走查方 略パターン及び 1 項目内での注視パターンの変化を前 半・中盤・後半*について検討する。

本研究の具体的な課題と仮説は次の通りである。

(1)認知スタイル間の走查方略の差異について：

「一般教示」下でSiegelman (1969), Drake (1970), 曰 井 (1975), 伎藤 (1976) が述べている視覚的走查方略 ゚゚ ターンに違いがあるかどうかについて検討する。次に

* 項目内の位圆は，全注視数を 3 等分し，最初の $1 / 3$ から前 半・中般・後半とした。総注視数が 3 の倍数ではないときの 余りはすべて後半に入れた。従って, 後半の位置は前半や中 盤より+1か十2になる場合も亦る。
「できるだけ正確に。誤りを犯さないように」という教 示 (「正確に」教示) によって衝動型と熟慮型の視覚的走 查方略パターンに変化がみられるかどうか検 討する。 「失敗することへの不安の強いこと」が熟慮型の先行変 数であれば，「正確に」教示は熟慮的な走查方略を強め るように㗢くと考えられる。

それゆえ,「一般教示」下においてみられる衝動型と 熟慮型間の走查方略の差異は「正確に。誤りを犯さない ように」という教示によって，熟虑型も衝動型も熟慮的 な方向へ変化するであろう。

(2)第 1 項目から第12項目までの時系列的な変化につい $\tau:$

走査方略に関する従来の研究では12項目全体について 認知スタイル間の比較が行われてきた。しかし，失敗経 験や課題への慣れ，解決の方略の発見や変化などによ り, 本来の認知スタイルの特徵が相殺されてしまう可能 性がある。MFFT の第 1 項目から第 12 項目までを前 半・中盤・後半の 3 つの過程に分け, 衝動型と熟慮型を 比較することによって課題解決過程の変化過程をとらえ ることができる。

「一般教示」下での衝動型と熟慮型の関係は前半の 1 3 の項目においては差異があるが，後半の10-12の項目 ではその差異はなくなるであろう。

(3) 1 課題内での差異について :

「一般教示」下では熟虑型は課題解決の最初の段階では その多くの側面について情報を収集し，次第にそれらの 情報を操作・処理し課題解決に必要な情報を絞り込んで いくと考えられる。それゆえ，1 項目内での各方略の出 現率は項目内の前半では標準刺激を中心とした比較の割 合が高いが，項目内の後半になるにつれて比較刺激間の 比較を中心とした比較の割合が高くなるであろう。しか し，衝動型はどの段階にあっても課題を正確に解決する ために必要なすべての情報を収集しないうちに反応する ので 1 課題内での各方略の出現率に変化はみられないで あろう。

「正確に」教示下では, 熟虑型も衝動型も比較過程の最 初から多くの情報を収集するようになり, 衝動型と熟慮 型間の差はみられないであろう。

\section{方法}

\section{実験計画}

本研究の独立変数は教示 (一般的・正確さの 2 水準), 認 知スタイル（衝動型・熟虑型の 2 水準），12項目中の位置 (前半 $(1-3) \cdot$ 後半 $(10-12)$ の 2 水集), 各項目内での位置 (前半・中艋・後半の 3 水準) であった。そのうち後の $2 つ$ 
の要因は被験者内要因であった。従属変数は反応潜時と 誤反応数, 注視回数と注視パターン（視覚的走查方略）で あった。

\section{被験者}

44名の被験者のうちアイマークが明確でなかった者 8 名と中央值折半法によって分類できなかった者11名を除

き，各認知スタイルの典型的な者から順に16名であった。 被験者の平均年齢は20歳 3 か月であった。

注視点測定装置

$\mathrm{nac}$ 社製アイマークレコーダー（モデル 4) であり，そ れを第 2 セッョンに入る前に装着した。

\section{手 続}

(1)第 1 セッション（認知スタイルの判定）

各被験者の認知スタイルを測定するために MFFT (Kagan, 1967) を実施した。MFFT は標準刺激を中心に， 比較刺激をその回りに円形に配置した。

「考える時間は自由です」という主旨の一般教示を与え た。

(2)第 2 セッション（条件の設定と効果の測定）

第 1 セッションの結果に基づいて各認知スタイル 8 名 の被験者を選び，第 1 セッションの約 1 週間後から MFFT 2 (山崎, 1976) を実施した。実験群（各スタイル 4名)には「正確に。誤りを犯さないように」と強調し た教示 (「正確に」教示)を，統制 群 (各スタイル4名)に はセッション 1 と同じ一般教示を与えた*。刺激の配 置 は MFFT と同じであった。第 2 セッションの前に「課 題は前回とは異なるが，同種類の課題を実施する」と告 げた。その後,アイマークレコーダーの装着による違和感 を除くためにレコーダーを着けて簡単な練習用 MFFT を実施し，その後 MFFT 2 を実施した。

(3)反応パターンの分析**

被験者の反応パターンを次の6つのタイプに分けて分 析した。

リターン 1 は標準刺激 (SS) 一比較刺激 $\left(\mathrm{SV}_{\mathrm{i}}\right)$ 一標準 刺激 (SS), リターン 2 は $\mathrm{SV}_{\mathrm{i}}-\mathrm{SS}-\mathrm{SV}_{\mathrm{i}}$, リターン 3 は $\mathrm{SV}_{\mathrm{i}}-\mathrm{SV}_{\mathrm{j}}-\mathrm{SV}_{\mathrm{i}}$, ラン 1 は $\mathrm{SS}-\mathrm{SV}_{\mathrm{i}}-\mathrm{SV}_{\mathrm{j}}$, ラン 2 は $\mathrm{SS}-\mathrm{SV}_{\mathrm{i}}-\mathrm{SV}_{\mathrm{j}}-\mathrm{SV}_{\mathrm{k}}$, ラン 3 は $\mathrm{SS}-\mathrm{SV}_{\mathrm{i}}-\mathrm{SV}_{\mathrm{j}}$ $\mathrm{SV}_{\mathrm{k}}-\mathrm{SV}_{1}$ のパターンを示すものとした。

\section{結果}

標準刺激注視率は, 衝動型では項目 1-3が.431, 項目 10一12が.376，熟慮型ではそれぞれ.383と.401であった。 項目 1--3 では衝動型が熟慮型よりも有意に高い傾向*** が見られた $(t=1.668, d f=10, p<.10)$ が，項目 $10--12$ で はそのような傾向はみられなかった。
TABLE 1 Mean number of the total fixation points. $* * * *$

\begin{tabular}{c|cccc}
\hline Style & \multicolumn{2}{|c}{ Reflective } & \multicolumn{2}{c}{ Impulsive } \\
\hline Item & $1-3$ & $10-12$ & $1-3$ & $10-12$ \\
\hline Norm. Inst. & $36.3(13.4)$ & $51.1(23.3)$ & $17.7(5.2)$ & $25.4(7.6)$ \\
\hline Cond. Inst. & $42.0(11.0)$ & $51.5(14.0)$ & $29.5(6.3)$ & $37.3(14.5)$ \\
\hline
\end{tabular}

( )内は S D

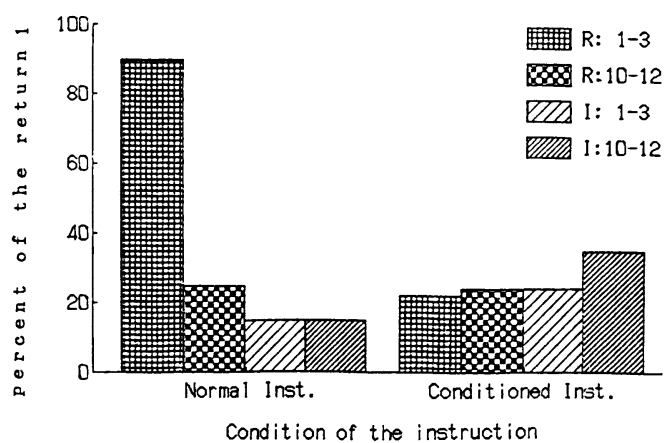

FIG. 1-1 Percent of return 1; first

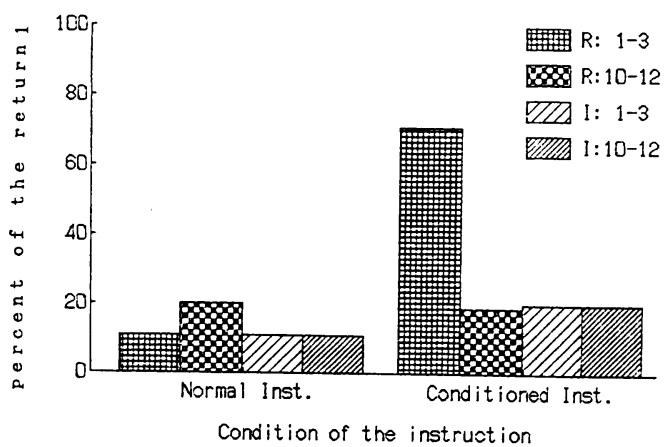

FIG. 1-2 Percent of return 1; middle

*「正確に」教示群については, 䛊反応に対して「違います, 正確に, 湂りを犯さないように」とフィードバックし，それ 以外に 3 項目ごとに同じ教示を与え，正反応に対しては「そ らです」といらフィードバックをした。統制群てついては反 応ごとに誤反応に対して「違います」，正反応に対して「そ らです」とフィードバックした。

** 例えば, SS-SVi-SS-SVi ではリターン 1 とリターン 2 が各 1 回である。

*** 結果を分析するにあたり，分散分析， $\mathrm{t}$ 検定および多重 比較においては有意水準を $5 \%$ とし，有意な傾向について は $p<.25$ とした。なお，主効果と交互作用がともに有意 であったり，傾向があった場合には交互作用のもつ意味を 重視したので，その交互作用にかかわるすべての平均值間 の多重比較を行った。

**** TABLE 1 の数值は項目 $1-3,10-12$ の注視数の合計の 平均である。 
総注視数に占めるそれぞれの反応パターンの出現率に 基づいて，各認知スタイルに特有な方略があるかどうか を検㙅した。

総注視数に占めるリターン 1 の割合についての 4 要因 （教示 $\times$ 認知スタイル $\times$ 項目内の位置 $\times$ 項目位㯰）分散分析の 結果, 教示の主効果 $(F(1 / 90)=3.83, p<.053)$, 項目内の 位置の主効果 $(F(2 / 90)=3.31, p<.041)$ が有意であり，教 示 $\times$ 項目内の位置の交互作用 $(F(2 / 90)=2.92, p<.059)$ 之 教示 $\times$ 認知スタイル $\times$ 項目内の位置 $\times$ 項目の交互作用 $(F(4 / 90)=1.40, p<.241)$ に有意な傾向がみられた。

そこで項目内の位置ごとに多重比較をした結果, 項目 内の前半では前半の項目1-3の「一般教示」での熟慮型 は他のすべての条件（同じ教示下での項目10-12の熟慮型・ 衝動型, 項目1-3での衝動型,「正確に」教示下での項目1-3の 熟虑型・衝動型, 同じ教示下での項目10-12の熟虑型・衝動型) より有意に高かった（それぞれ，t=12.030，t=11.041，t= 10.711, $t=7.377, t=8.984, t=7.055, t=7.598$, いずれも $d f$ $=28, p<.01)$ このことは, 熟慮型では項目内の前半の 「正確に」教示下では前半の項目1一3においてリターン 1 の割合が低下し, さらに, 熟慮型では「一般教示」下 での前半の項目は後半の項目よりその方略の出現率が高 いことを示している。

項目内の中盤の結果は「正確に」教示下の前半の項目 1-3の熟慮型が他の条件 (「一般教示」下の熟虑型の前半の 項目 $1-3$ と後半の項目 10-12, 同じく衝動型の前半の項 目 1-3 之後半の項目 10-12,「正確化」教示下の熟虑型の後半の項目 10 -12 , 同じく衝動型の前半1-3和よび後半の項目 10-12）より もその割合が高かった（多重比較の結果，それぞれ， $t=$ 7. 390, $t=6.222, t=7.467, t=6.824, t=5.061, t=5.571, t=$ 5.725 , いずれも $d f=28, p<.01)$ 。このこと, 項目内の中 盤に扔いては熟慮型では「正確に」教示下での前半の項 目1一3のリターン 1 の割合が上昇したこと，また，「正 確に」教示下の熟慮型では前半の項目 1-3は後半の項目 10-12よりもその割合が有意に高いことを示している。 さらに, 前半の項目 1 - 3 の正確に」教示下の衝動型は 同じ条件の「一般教示」の衝動型より高い傾向がみられ $(t=1.855, d f=28, p<.10)$, リターン 1 の割合が「正確 に」教示によって高くなる傾向を示している。

総注視数に占めるリターン 2 の割合についての 4 要因 (教示 $\times$ 認知スタイル $\times$ 項目内の位置 $\times$ 項目位固) 分散分析 の 結果, 教示 $\times$ 認知スタイルの交互作用にのみ有意な傾向 がみられた $(F=(1 / 90)=1.93, p<.168)$ 。多重比較の結果, 「一般教示」下の熟虑型は衝動型よりも $(t=3.364, d f=110$, $p<.01) ， 「 一$ 般教示」下の熟慮型は「正確に」教示下の 熟虑型よりも有意にその割合が高かった $t=1.969, d f=$

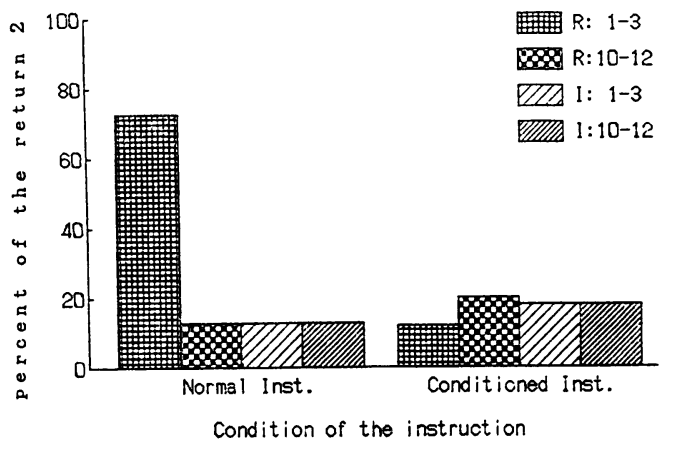

Fig. 2-1 Percent of return 2; first

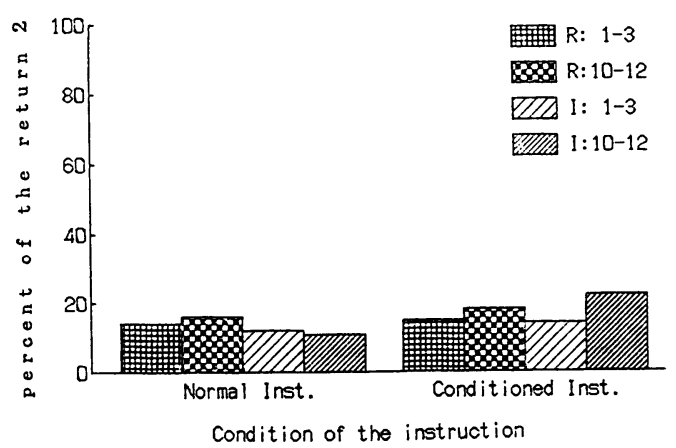

FIG. 2-2 Percent of return 2; middle

$110, p<.05)$ 。

「正確に」教示は熟慮型ではその割合を低下させるよう に衝いたが，衝動型にはそのようには㗢かなかった。

項目内の位置ごとに多重比較を行った結果，項目内の 前半では「一般教示」下の前半の項目 1 -3の熟慮型は同 じく後半の項目 10-12の熟虑型，同じく前半の項目 1-3 の衝動型，同じ教示下の後半の項目10-12の熟慮型と衝 動型,「正確に」教示下の項目 1-3の熟慮型と衝動型, 同じく項目10-12の熟虑型と衝動型より有意に高かった。 （それぞれ，t=12.573，t=12.531，t=11.478，t=8.443，t= $8.443, t=9.863, t=7.445, t=9.828$, いずれる， $d f=28, p<.01)$ 。 これは熟虑型ではリターン 1 と同様化項目内の前半にお いては「正確に」教示が前半の項目1-3のリターン 2 の 割合を低下させたことを示している。また，「一般教示」 下での熟虑型の前半の項目 1-3 後半の項目 10-12 との 差がみられ熟㦄型の前半の項目 1-3は後半の項目 10-12 よりもその割合が高いこと，どの項目位置においても衝 動型より有意に高く, 認知スタイル間で出現率に違いが あることを示している。

総注視数に占めるリターン 3 の割合について 4 要因 (教示 $\times$ 認知スタイル $\times$ 項目内の位置 $\times$ 項目位置) 分散分析の 結果, 教示 $\times$ 認知スタイル $\times$ 項目位置 $\times$ 項目内の位置の 


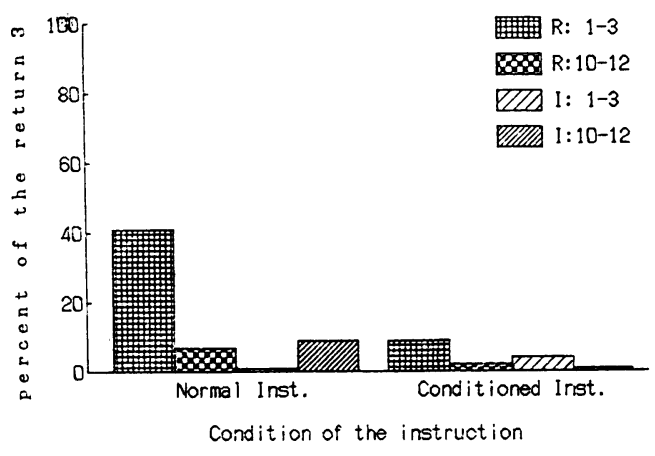

FIG. 3-1 Percent of return 3; first

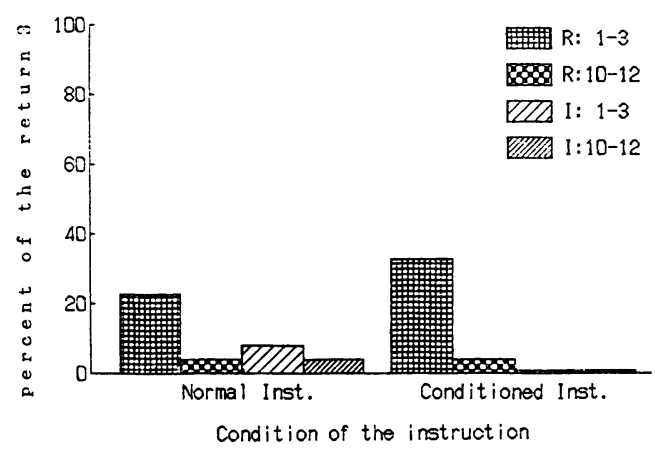

FIG. 3-2 Percent of return 3; middle 交互作用 $(F(4 / 90)=1.34, p<.260)$, 教示 $\times$ 認知スタイル $\times$ 項目位置の交互作用 $(F(1 / 90)=1.27, p<.264)$, 教示 $\times$ 項目位置の交互作用 $(F(1 / 90)=1.22, p<.272)$ について は $p<.27$ であったので，項目内の位置ごとに多重比較 を行った。

項目内の前半では，「一般教示」下の熟慮型は前半の 項目 1-3と後半の項目 10-12間, 同じく項目 1-3の街動 型，同じく項目10-12の衝動型，「正確に」教示下の 項 目1-3の熟慮型, 同じく項目10-12の熟慮型, 同じく項 目1-3の衝動型，同じく項目 10-12の衝動型よりその割 合が高かった（それぞれ，t=8.255, $t=9.760, t=7.092, t=$ 5. 131, $t=6.296, t=7.156, t=8.178$ ，いずれも $d f=28, p<.01$ )。 他の条件間には有意差はみられなかった。「一般教示」 下の前半の項目1--3では熟慮型が衝動型よりも出現率が 高く，「正確に」教示によってその差がなくなったこと を示している。

項目内の中盤では，熟㦄型の「一般教示」下の前半の 項目1-3での割合は，「一般教示」下での後半の項目 10 -12の熟慮型，同じく衝動型の前半の項目 $1-3$ と後半の 項目 10-12, 「正確に」教示下の熟慮型の後半の項目 10 -12 , 同じく衝動型の前半の項目 $1-3$ と後半の項目 $10-$ 12 上り有意に高かった（それぞれ， $t=4.975, t=4.029, t=$

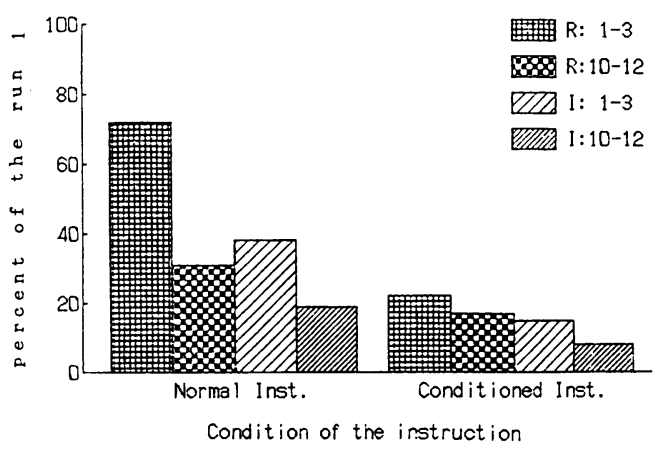

FIG. 4 Percent of run 1 ; first

4. 592, $t=3.425, t=4.935, t=5.051$, いずれも $d f=28, p<.01)$ 。 また，「正確に」教示下の項目1-3での熟慮型の割合は, 「一般教示」下での前半の項目1-3の衝動型, 後半の 項 目10-12の熟慮型, 同じく前半の項目 1-3の衝動型, 同 じく項目10-12の衝動型, 「正確に教示」下の後半の項 目10-12での熟慮型, 同じく前半の項目 1-3での衝動型, 同じく後半の項目 10-12の衝動型より有意に高かった (それぞれ，t=5.084, $t=4.453, t=4.907, t=4.163, t=5.208$, $t=5.291$ ，いずれも， $d f=28, p<.01)$ 。前半の項目 $1-3 に お$ いて「一般教示」下と「正確に」教示下での熟慮型の生 起率に差がみられず，「正確に」教示の効果はみられな かった。

項目内の後半についてはどの条件間にも有意差はなか つた。

総注視数に占めるラン 1 の割合についての 4 要因 (教 示×慜知スタイル $\times$ 項目内の位置 $\times$ 項目位置) 分散分析の結 果, 教示の主効果 $(F(1 / 90)=2.09, p<.152)$, 教示 $\times$ 項目 内の位置の交互作用 $(F(2 / 90)=2.45, p<.092)$ に有意な傾 向がみられた。

教示の効果と項目内の位置の交互作用について娭討す るために多重比較を行った結果,「一般教示」の項目内 の前半は「一般教示」下の中盤，同じく後半，「正確に」 教示下の前半，同じく中盤より有意にその割合が高かっ た（それぞれ，t=3.204，t=4.227, $t=3.609, t=3.412$,いずれ も, $d f=110, p<.05)$ ここれ「一般教示」下では項目内 の前半は中盤や後半よりラン 1 の割合が高いこと, 「正 確に」教示は項目内の前半においてラン 1 の割合を低下 させるように働いたことを示している。

総注視数に占めるラン 2 の割合についての 4 要因（教 示 $\times$ 認知スタイル $\times$ 項目内の位监 $\times$ 項目位圆 $)$ 分散分析の結 果, 認知スタイルの主効果 $(F(1 / 90)=6.52, p<.012)$ が有 意であり, 教示 $\times$ 認知スタイル×項目内の位置の交互作 用 $(F(2 / 90)=2.62, p<.078)$, 教示の主効喿 $(F(1 / 90)=$ 


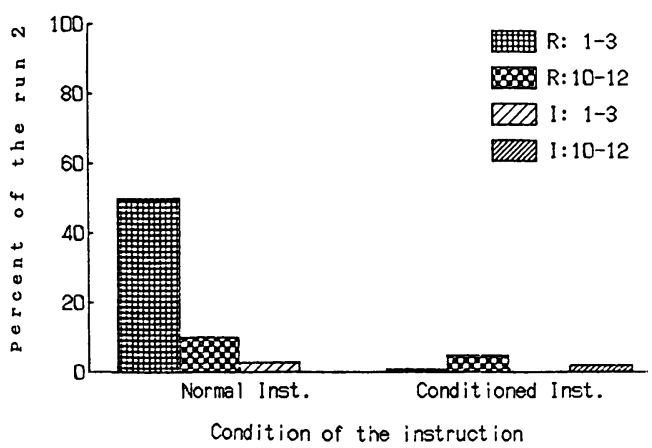

FIG. 5 Percent of run 2; first

$1.78, p<.184)$, 項目内の位置の主効果 $(F(2 / 90)=2.03$, $p<.137$ ), 認知スタイル $\times$ 項目内の位置の交互作用 ( $F$ $(2 / 90)=1.60, p<.207)$, 項目の位置の主効果 $(F(1 / 90)=$ $1.52, p<.220)$ に有意な傾向がみられた。

教示 $\times$ 認知スタイル $\times$ 項目内の位置の交互作用に有意 な傾向がみられたので，項目内の位置ごとに教示 $\times$ 認知 スタイルの值について多重比較を行った結果, 項目内の 前半では「一般教示」下の熟慮型は同じ教示の衝動型, 「正確に」教示下の衝動型, 同じく熟慮型よりも有意に その割合が高かった（それぞれ，t=5.161，t=4.693，t= 3. 406, いずれも, $d f=34, p<.05)$ 。「一般教示」下では熟 慮型は衝動型よりもラン 2 の方略をとることが多く, 「正確に」という教示は熟慮型の被験者のラン 2 の割合 を低下させるように働いたことを示している。

項目内の中盤では「一般教示」下での熟慮型が同じ教 示の衝動型，「正確に」教示下の衝動型よりも有意に高 $<(t=3.204, t=3.512$, いずれも $d f=34, p<.05)$, 「一般教 示」下で熟慮型は衝動型よりもラン 2 の方略をとること が多く，「正確に」という教示によるラン 2 の生起率の 変化はみられなかったことを示している。

項目内の後半ではどの条件間にも有意差はみられなか った。

このような結果から教示 $\times$ 認知スタイル $\times$ 項目内の位 置の交互作用は項目内の前半・中盤・後半では「正確 に」の教示の影響が異なっていること，その教示は衝動 型よりも熟慮型への影響が大きかったことなどによって 生じたと考えられる。

総注視数に占めるラン 3 の割合についての 4 要因（教 示 $\times$ 認知スタイル $\times$ 項目内の位置 $\times$ 項目位固) 分散分析の結 果, 認知スタイルの主効果 $(F(1 / 90)=1.74, p<.190)$, 教 示×認知スタイルの交互作用 $(F(1 / 90)=1.41, p<.238)$ に 有意な傾向がみられた。その他の主効果や交互作用は有 意ではなかった。

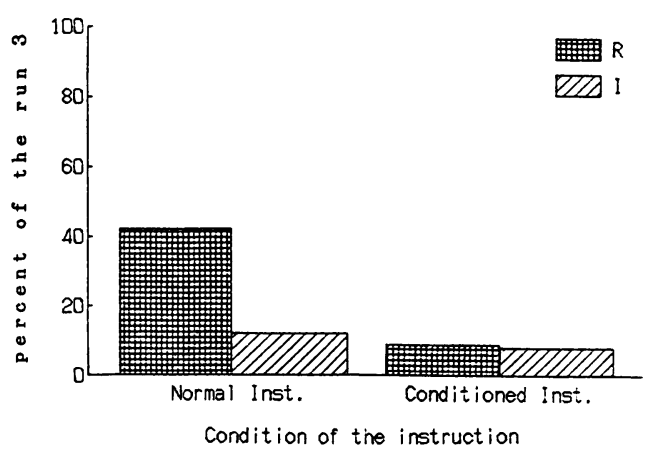

Fig. 6 Percent of run 3

多重比較の結果，「一般教示」下の熟慮型は同じ教 示 の衝動型，「正確に」教示下の熟慮型や衝動型よりもラ ン 3 の割合が有意に高かった(それぞれ， $t=3.058, t=2.748$, $t=2.361, p<.05$, いずれも， $d f=110)$ 。これは「一般教示」 下において熟慮型は衝動型よりもラン 3 の方略をとるこ とが多く，「正確に」という教示が熟慮型のラン 3 の割 合を低下させるように働いたことを示している。

次に, 課題解決過程内の処理方略の時系列的変化につ いて検討するために「一般教示」下の条件に限って項目 内の前半・中盤・後半における条件間の差について前半 の項目 1--3と後半の項目 10-12別に多重比較を行った。 その結果，リターン 1 については熟慮型の前半の項目 1一3において項目内の前半は中盤や後半よりも，後半は 中盤よりも生起率が高かった(それぞれ， $t=16.664, p<.05$, $t=13.788, p<.02, t=2.887, p<.05$, 小ずれも,$d f=18)$ 。後 半の項目10-12については前半は中盤や後半より生起率

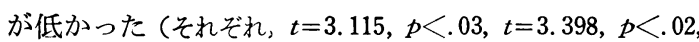
いずれも， $d f=18)$ 。 リターン 2 については熟慮型の前半 の項目 1 -3において項目内の前半が中盤や後半よりもそ の割合が有意に高った（それぞれ，t=6.851, p<.05, $t=$ $6.155, p<.02$, いずれも $d f=18)$ 。リターン 3 について熟慮 型の前半の項目 1 -3では項目内の前半が中盤や後半より も，中盤は後半よりも有意に高った(それぞれ， $t=19.952$, $p<.01, t=9.401, p<.01, t=10.551, p<.01$, いずれも $d f=18$ )。 ラン 1 については熟慮型の前半の項目1-3では項目内の 前半の方が後半や中盤よりも有意にその割合が高かった (それぞれ, $t=12.331, p<.01, t=10.453, p<.01$ ，いずれも $d f=18)$ 。ラン 2 については熟慮型の前半の項目 $1-3$ で は項目内の前半と中盤は後半よりも有意に高かった（そ れぞれ, $t=14.751, p<.01, t=15.607, p<.01$, いずれも $d f=$ 18)。ラン 3 については熟慮型の前半の項目 1-3では 項 目内の前半は後半や中盤よりも有意にその割合が高かっ た（それぞれ，t=8.090,p<.05, $t=8.164, p<.05$, いずれも 
$d f=18)$ 。その他には有意差はなかった。

このように熟慮型は前半の項目 1-3では項目内の位置 によってそれぞれの方略パターンの生起率が変化するこ と, とくに項目内の前半では各方略パターンの生起率が 高くなる傾向を示している。しかし，衝動型については このような傾向はみられなかった。すなわち, 前半の項 目1-3においては, 熟慮型は項目内の前半では中盤や後 半に比べて, 個別の比較刺激との比較をする割合が高く (リターン 1 ・ 2 の結果), また比較刺激間を比較する方略 パターンの出現率も高かった (リターン 1, ラン $1 \cdot 2 \cdot 3$ の結果)。

\section{考察}

本研究においては継時的な比較パターンとしてリター ン $1 ， 2 ， 3$ とラン $1 ， 2 ， 3$ を取り上げた。このよう な比較パターンは, 標淮刺激と基準とした比較と選択刺 激間の特徵の違いを見つけ出すための比較刺激間の比較 は意味が異なると考えられる。さらに，標準刺激に対す る依存度が高いと考えられる衝動型はリターン 3 , ラン $2 ， 3$ のような方略はとりにくくなるであろう。従って， 本研究では, 認知スタイルの走查方略の差異を明らかに するために，リターン $1,2 ， 3$ ，およびラン 1,2 ， 3 にわけて分析した。衝動型ではリターン 1 , ラン 1 が 他のパターンより生起率が高くなり, 熟慮型ではリター ン 2,3 およびラン 2,3 の生起率が高くなると考えら れた。

結果で述べたように，一般教示下において衝動型と熟 慮型間に有意差がみられたのはリターン1・2・3（前 半の項目 1 -3の項目内の前半), ラン 2 (項目内の前半), ラ ン 3 (条件にかかわらず)であった。

したがって，「一般教示」下に扔いて熟虑型と衝動型 間で走査方略に差がみられるだろうという仮説は完全に は支持されなかった。また, 本研究の結果は Zelniker et al. (1972) や Ault et al. (1972) の『...標準刺激と比 較刺激間の同一部分比較であるリターンの全注視数に占 める割合についてのみ衝動型と熟慮型間に差がみられる が，本質的には各認知スタイルに特有の走查方略はな い』とは必ずしも一致しないものであった。さらに佐藤 (1976)の『「同一部分比較」「連続比較」など組織的な比 較パターンを用いることについての衝動型と熟慮型の間 には本質的な差がない』とも一致していない。このよう な違いが生じた原因としては次のようなことが考えられ る。

(1)本研究の MFFT 課題とこれまでの研究で用いられ た MFFT 課題の困難度と被験者の年齢の問題, すなわ
ち, 本研究で用いた MFFT 2 は従来のものより反応潜 時は長く嚜反応数は多く困難度が高かった。加えて被験 者が大学生であったので, 試行を重ね正誤のフィードバ ックが繰り返されるにつれて本研究で分析しなかった方 略を使うようになり，「一般教示」下の後半の項目 10一 12や項目内の後半では認知スタイル間に差がみられなく なったと考えられる。

(2)MFFT の提示方法の違いすなわち, MFFT 課題 を提示する際に従来は標準刺激を上に比較刺激をその下 2 行に配列して提示する方法がとられてきた。しかし， 小嶋（1975）が指摘するように衝動型はそのような 提示 方法においては標準刺激の真下に位置する刺激への反応 が多く，選択位置の偏好を起こしやすい。したがって， 従来の方法では本来の各被験者のもつ特有の認知スタイ ルの走查方略の出現を妨害していた可能性もある。本実 験では刺激を標準刺激を中心に比較刺激をその周りに円 形に配置して提示したので, 各被験者のもつ本来の走査 方略パターンが現れたと考えることもできる。

(3)分析方法の違いこれまでの研究では全項目がまと めて分析されたが, 本研究で明らかにされたように衝動 型と熟慮型の差は項目の位置 (前半 $(1-3)$ と後半 $(10-12)$ ) や項目内の位置 (前半・中盤・後半) によって異なってい た。認知スタイル間の差異は項目内の前半において顕著 にみられるものであった。このような結果は, 視覚的走 査方略について衝動型と熟慮型間に差があるとする Siegelman (1969), Drake (1970), 臼井 (1975) の結果 を支持するものであった。

次に，「正確に」教示によって出現率が低下したのは， （）内の条件下でのリターン 1 (熟虑型の前半の項目 $1-3 \cdot$ 項目内の前半), リターン 2 (条件にかかわらす熟虑型), リ ターン 3 (熟慮型の前半の項目 $1-3$ ・項目内の前半), ラン 1 (認知スタイル・項目位固にかかわらず項目内の前半), ラン 2 (条件にかかわらず熟虑型の項目内の前半), ラン 3 (条件にか かわらず熟慮型) であった。これとは逆に「正確に」教示 によって出現率の上昇がみられたのはリターン1（項目 内の中盤・前半の項目 $1-3$ ・熟慮型および衝動型), リターン 3 (項目内の中盤・前半の項目 $1-3 \cdot$ 熟慮型) であった。 「正確に」教示によって認知スタイル間の有意差はみら れず傾向を示したが，その方向は熟慮型方略の特徵を示 すものではなく仮説は支持されなかった。このような結 果の得られた理由は次のように考えられる。第 1 に正 確に」教示によって項目の後半になるにつれて次第に刺 激の特徴的な部分の比較をするために離れた SV 間の比 較をするなど，本研究で分析した以外の方略を用いた可 能性もある。 
第 2 に宮川（1977）の言うように，熟慮型の被験者は 衝動型に比べて柔軟性が高く，与えられた環境に対して 柔軟に対応することができたことによる可能性がある。 本研究における熟慮型の走查方略の出現率の変化はその ような柔軟性の高さによると考えることができる。教示 と項目内の位置の違いによる熟慮型被験者の生起率の変 動は, リターン $1 \cdot 2 \cdot 3$ やラン $1 \cdot 2$ の前半の項目 1一3において大きかった。これは熟慮型の柔軟性が高く 課題解決過程の各段階に対応した走查方略を用いること を示していると考えられる。

この点に関する第 3 の示唆は Reali \& Hall (1970) の研究から得られる。彼女らは課題解決の失敗の後では 成功への期待が弱まり，その結果としてより注意媣い反 応が行われやすくなることを明らかにした。本研究にお いても後半の項目 $10-12$ や項目内の後半になると失敗経 験が重なり成功への期待が弱まり, 結果としてょり慎重 な走查方略や標準刺激を中心とした比較方略パターンが 增加し, 熟慮型と衝動型の差がなくなった可能性も考え られる。

1 項目から12項目亡での時系列的な変化は，「一般教 示」下の熟慮型のリターン 1 ・ 2 ・ 3 においてみられ, いずれの方略も前半の項目1-3より後半の項目 10-12で の生起率が低く, 後半の項目10-12ではこれらの方略を とらなくなることを示している。熟虑型の被験者の内省 報告においても「後の項目になるにつれて慎重になっ た」という報告があった。このような被験者の内的変化 は選抧の誤りに対する「違います」というフィードバッ ク経験の積み重ねや課題に対する構え, 課題解決方略の 固定などによって生じた可能性がある。本研究で用いた MFFT 2 は Zelniker \& Jeffrey (1977) の言う詳細な 部分を含んだ (detail) 課題であり，正答を得るためには 慎重に選抧しなけれ壮ならない。それゆえ, 後半になっ て, 結果のフィードバックなどによってより慎重な反 応・方略をとるようになったと考えられる。しかし，本 研究の分析だけでは十分上は言えず, 課題の属性（例え ば，複雑さ）との関連などを考虑し，さらに詳細に検討 しなければならない。

本研究のもう 1 つの䦓題は 1 課題内での比較過程の変 化について検討することであった。熟慮型は最初に多く の比較刺激を比較するが次第にその数は減少していくで あろうと予想した。熟虑型では「一般教示」下の前半の 項目1-3に扝いて分析したすべての方略パターンの中で 項目内の前半が中盤 (ラン 2 を除いて) や後半よりも高い 生起率であったので, 熟慮型は前半の項目 1 -3では走査 方略パターンが変化するといえる。すなわち, 本研究で
分析したような方略パターンの出現率が次第に低下する ことを示しており, 項目内の中盤から後半にかけて本研 究で分析した方略と異なった方略を用いるようになる可 能性が示唆された。前半の項目1-3でしかも項目内の前 半では本来熟慮型の被験者のもっている走查方略によっ て整然とした比較をしていても，次第に正答にかかわる と思われる比較刺激について検討していくようになり， 単純に隣りどうしの刺激間の比較や標準刺激と比較刺激 の単純な比較が少なくなると考えられる。熟慮型は多く の情報の中からいくつかの仮説を生成しそれらの 1 つひ とつを検証していく。そのために正答と考えられる比較 刺激に絞り込んでいく方略をとり, 単純に隣りあう刺激 や標準刺激と比較をすることが少なくなると予想される。 本研究では前半の項目1-3の熟虑型においてのみこれに 関する仮説は支持された。しかし，この問題については 特定の比較刺激との比較がどのように変化したかなどさ らに細かな分析によって結論を出さなければならない。

全体として, 認知スタイルの特徴は一般的教示下の前 半の項目1-3の, しかも項目内の前半においてみられた。 すなわち, 本研究では熟慮型の走査方略の特徵は課題に 取り組んだ最初の段階であらわれた。しかし，その特徴 はその後反応に対する正誤のフィードバックや失敗経験 などによって消失したと考えられる。このように一時的 であったが熟慮型の認知スタイルの特徴があり, 衝動 型・熟虑型の次元の先行変数として「誤りに対する不 安」を考えることができる。

さらに，これまでの研究で言われてきたように，熟虑 型は課題の要件や状況に忘じて行動を変えることができ たが，衝動型はそうではなかった。それゆえ，教育場面 においても各認知スタイルの特翼を十分に考慮した指導 をする必要があると考えられる。

\section{引用文献}

Ault, R.L. Crawford, D.E., and Jeffrey, W.E. 1972 Visual scanning strategies of reflective, impulsive, fast-accurate, and slow inaccurate children on Matching Familiar Figures test. Child Development, 43, 1412-1417.

Brockner, J. 1979 Self-esteem, self-consciousness and task performance: Replication, extention, and possible explanation. Journal of Personality and Social Psychology, 37, 447--461.

Drake, D.M. 1970 Perceptual correlates of impulsive and reflective behavior. Developmental Psychology, 2, 202--214. 
Kagan, J., Kogan, N. 1970 Individuality and cognitive performance. In P.H. Mussen (Ed.), Carmichael's Manual of Child Psychology. 3rd ed. Harper \& Row, Pp. 1273-1365.

小嶋秀夫 1975 児童用 MFF の分析 日本心理学会第 39回大会発表論文集, 488.

宮川充司 1977 認知的衝動性の変容可能性 日本心理 学会第41回大会発表論文集, 834-835.

Reali, N. and Hall, V. 1970 Effect of success and failure on the reflective and impulsive child. Developmental Psychology, 3, 392-402.

仿藤公治 1976 MFF 課題における視覚的走査方略に 関する研究 教育心理学研究, 24, 224-234.

田中良枝 1984 認知スタイルの規定要因一認知スタ イルと自尊心一 滋賀大学教育学部昭和58年度卒業 論文 幼児心理学 (未刊).

臼井博 1975 認知スタイル (Reflection-Impulsivity) に関する心理学的研究：I一視覚的探索ストラテジ 一の分析一 教育心理学研究, 23, 10-20.

山崎晃 1976 認知スタイルの変容に関する発達的研究 教育心理学研究 24, 190-194.
Siegelman, E. 1969 Reflective and impulsive observing behavior. Child Development, 40, 12131222.

Zelniker, T., Jeffrey, W.E., Ault, R., and Parsons, J. 1972 Analysis and modification of search strategies of impulsive and reflective children of the MFF test. Child Development, 43, 321335.

Zelniker, T. and Jeffrey, W.E. 1977 Reflective and impulsive children: Strategies of information processing underlying differences in problem solving. Monograph of the Society for Research in Child Development, 41, (serial no. 168), 5.

本研究のデータの分析のほとんどは京都大学大型計算 機センターの SAS によって行った。

[謝辞]

本研究をまとめるにあたり, 広島大学祐宗省三教授に御 指導を頂いた。ここに記して謝意を表します。

（1986年 4 月 21 日受稿） 